\title{
A review of some common Indo-Malayan and western Pacific species of Chthamalus barnacles (Crustacea: Cirripedia)
}

\author{
A.J. Southward* and W.A. Newman ${ }^{\dagger}$ \\ * Marine Biological Association, Citadel Hill, Plymouth, PL1 2PB. \\ ${ }^{\dagger}$ Scripps Institution of Oceanography, University of California-San Diego, La Jolla, CA 92093, USA. \\ *Corresponding author, e-mail: ajs@mba.ac.uk
}

\begin{abstract}
The type specimens of the common tropical intertidal barnacles Chthamalus malayensis and C. moro, were re-investigated and compared with other specimens of Chthamalus from the Indian Ocean, Indo-Malaya, northern Australia, Vietnam, China and the western Pacific, using 'arthropodal' as well as shell characters.

Chthamalus malayensis occurs widely in Indo-Malayan and tropical Australian waters. It ranges westwards in the Indian Ocean to East Africa and northwards in the Pacific to Vietnam, China and the Ryukyu Islands. Chthamalus malayensis has the arthropodal characters attributed to it by Pope (1965); conical spines on cirrus 1 and serrate setae with basal guards on cirrus 2.

Chthamalus moro is currently fully validated only for the Philippines, Indonesia, Taiwan, the Xisha (Paracel) Islands, the Ryukyu Islands, the Mariana Islands, the Caroline Islands, Fiji and Samoa. It is a small species of the 'challengeri' subgroup, lacking conical spines on cirrus 1 and bearing pectinate setae without basal guards on cirrus 2. It may be a 'relict' insular species.

Chthamalus challengeri also lacks conical spines on cirrus 1 and has pectinate setae without basal guards on cirrus 2. Records of $C$. challengeri south of Japan are probably erroneous. However, there is an undescribed species of the 'challengeri' subgroup in the Indian Ocean, Indo-Malaya, Vietnam and southern China and yet more may occur in the western Pacific. The subgroups 'malayensis' and 'challengeri' require genetic investigation.
\end{abstract}

Some comments are included on the arthropodal characters and geographical distributions of Chthamalus antennatus, C. dalli and C. stellatus.

\section{INTRODUCTION}

Species of the genus Chthamalus Ranzani 1817 are difficult to identify because of their great variation in external morphology (Southward, 1983; Dando, 1987; Southward et al., 1998). This was noted by earlier generations of cirripede workers, including Darwin (1854), Pilsbry (1916), Nilsson-Cantell (1921), Utinomi (1954) and Pope (1965). Over the years it became evident that more attention should be given to internal characters, particularly the cirral appendages and trophi, collectively called the 'arthropodal' characters, though these do not always separate closely related species. Darwin (1854) spent some time examining these microscopic features, having purchased a high-quality compound microscope, now in the possession of the Botany School at Cambridge, England. Pilsbry (1916) extended the study and employed the morphology of the mandible to separate subgenera, for example the 'hembeli' group and the 'stellatus' group. Nilsson-Cantell (1921) extended the use of the mandible to distinguish subgroups and species, and looked further at the setae of cirrus 2. However, even today not all species of Chthamalus have been properly investigated for characters of the cirri and trophi. The need to examine such arthropodal characters has recently been stressed (Southward et al., 1998; Poltarukha, 2001a,b). The most useful characters are the form of the complex setae found on the distal segments of the second cirrus and the presence or absence of conical spines on the outer (anterior) ramus of the first cirrus. Figure 1 shows outline sketches illustrating the features of cirri 1 and 2 and the mandible of use in identification and classification. Additional internal characters that have also been used are the shape and position of the adductor muscle scar inside the scutum and measures of the proportions of the mandible and maxillule, but these are more variable (Dando \& Southward, 1980). Biochemical genetic characters can help separate closely related species and possible subspecies (Hedgecock, 1979; Dando \& Southward, 1980; Miller et al., 1989; Pannacciulli et al., 1997; Southward et al., 1998; Wares, 2001). They are not universally applicable since dry type material in collections cannot be used for isozyme studies, and formol or ethanol preserved specimens may not retain sufficient undamaged DNA for amplification.

Especial confusion has arisen about the status of the common Chthamalus species on the shores of the IndoMalayan region, northern Australia and the Philippines. Few of the early authors looked fully at the arthropodal characters and those who did made understandable mistakes. Poltarukha (2001a,b) has attempted a revision of the two dominant species that occur in this area, 


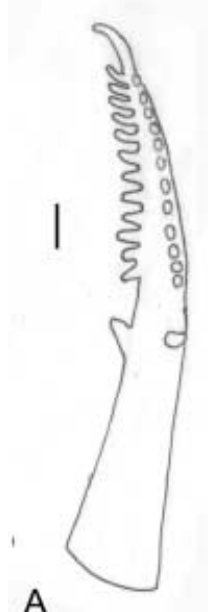

A
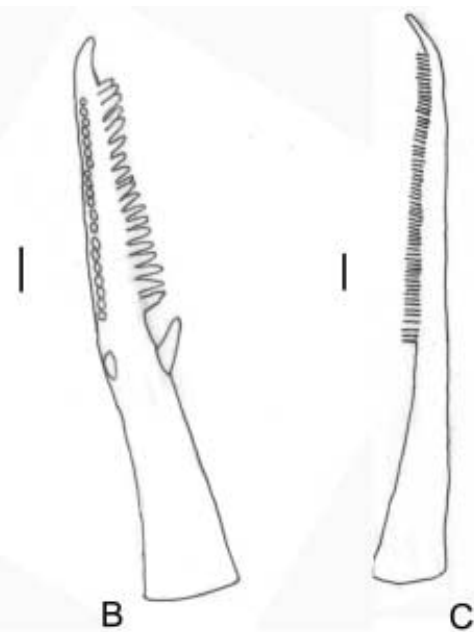

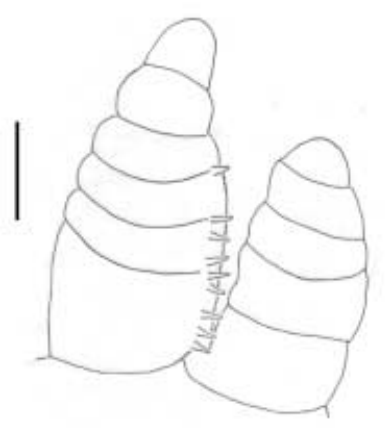

D

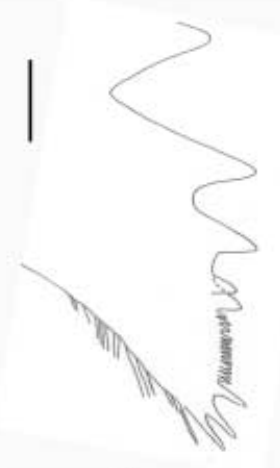

E
Figure 1. Outline drawings of setal and mandibular characters used for identifying Chthamalus species. (A) Serrate seta with basal guards; (B) somewhat finer serrate seta with basal guards; (C) finely pectinate seta without basal guards (only one side shown); (D) cirrus 1 of Chthamalus malayensis showing conical spines on the inner side of the outer (anterior) ramus, setae omitted for clarity; (E) mandible of $C$. malayensis showing, from top to bottom, four prominent teeth, of which the fourth is double, then the pecten of 13 small teeth, then the three teeth at the lower angle. Scale bars: A-C, $10 \mu \mathrm{m} ; \mathrm{D}, \mathrm{E}$, $100 \mu \mathrm{m}$.

erected by Pilsbry (1916). These are: Chthamalus malayensis Pilsbry 1916, originally described from a sample collected in the 'Malay Peninsula', and C. moro Pilsbry 1916, originally described from material collected at Zamboanga in the southern Philippines. Figure 2 shows the external appearance of these two species, as seen in samples from Taiwan. Pilsbry did not study the arthropodal characters of C. moro, and his description of these aspects of C. malayensis is deficient. Until recently, the published description of the trophi and cirri could not be checked as the microscope slide of the type was mislaid, as noted by Pope (1965). This has produced further confusion in some recent publications on the group (Poltarukha, 2001a,b). From a mistaken reading of Pilsbry (1916), who did not in fact observe the arthropodal characters of $C$. moro, and from confused descriptions by later authors, Poltarukha (200la,b) decided that Vietnam specimens of Chthamalus with conical spines on cirrus 1 , and with basal guards on the complex setae of cirrus 2, must be C. moro; and material lacking these characters must be $C$. malayensis. This decision contradicted the opinion of Pope (1965),
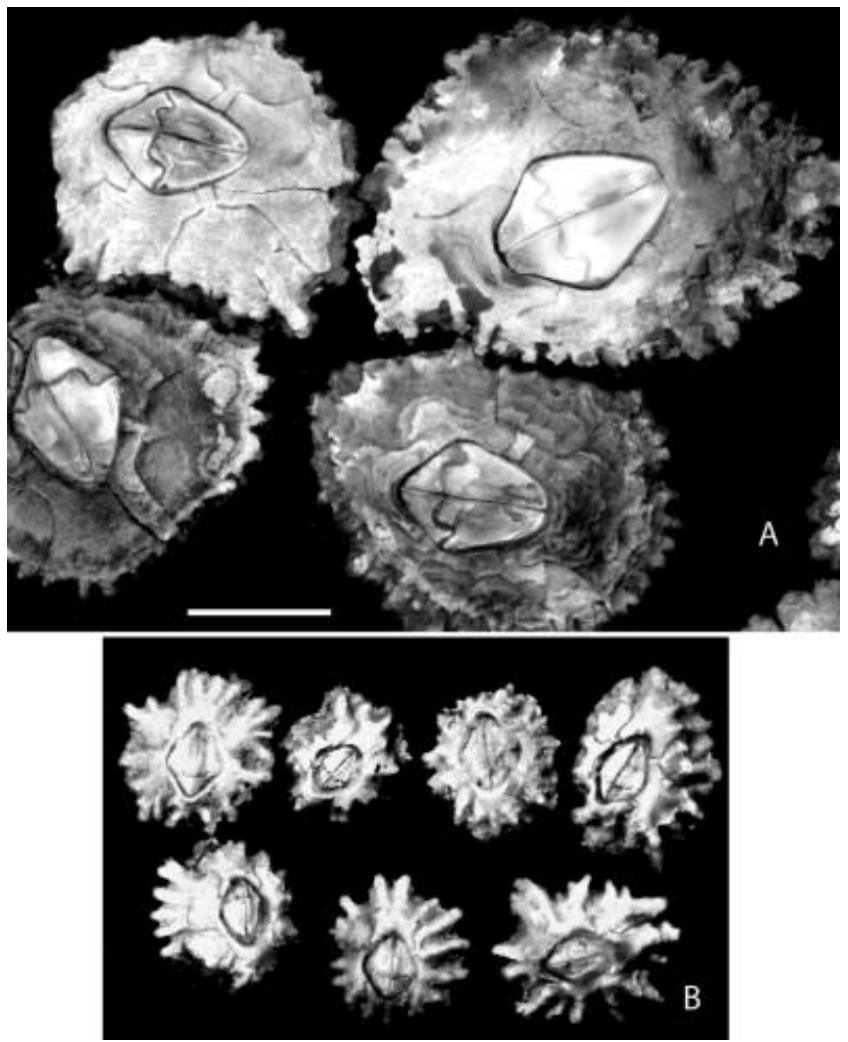

Figure 2. Photographs of (A) Chthamalus malayensis; and (B) Chthamalus moro to the same enlargement to show the prominent ribbing of the parietes in C. moro. Scale bar: $5 \mathrm{~mm}$. Collected by P.-H. Chen at Patoutzu, Keelung, Taiwan.

who reviewed the Indo-Malayan species of Chthamalus and stated that the common species in northern Australia was $C$. malayensis and that it had conical spines on the first cirrus and complex setae with basal guards on the second cirrus. Dando \& Southward (1980) and Southward et al. (1998) used Pope's characters to assign C. malayensis as the key species in a subgroup of Chthamalus (Table 1).

\section{MATERIALS AND METHODS}

The type specimens of Chthamalus malayensis and C. moro loaned by the National Museum of Natural History, Washington (NMNH) and the Academy of Natural Sciences of Philadelphia (ANSP) were examined. Additional material was borrowed from the Zoological Museum, Copenhagen (ZMC) and the Senckenberg Museum, Frankfurt. As Pope (1965) reported, the microscope slide of $C$. malayensis prepared by Pilsbry was not catalogued at ANSP, but diligent searches by Dr G. Rosenberg located it there. This slide was dried up, as were other glycerine jelly preparations made by Pilsbry (Zullo, 1968). The slide was rehydrated by several days soaking in water on a hot plate at $40^{\circ} \mathrm{C}$. Cover slips were removed and the appendages remounted in fresh glycerine jelly. Not all the original jelly could be fully softened and there are some air bubbles in the remounted preparations, but it is possible to discern and photograph the arthropodal features.

The dried paratypes of C. moro included some intact individuals with body and opercular plates, and two of these were successfully rehydrated and softened in dilute 
Table 1. Subgroups of the stellatus section of Chthamalus: those having a quadridentate mandible with a pecten of fine teeth and without interdigitate sutures between the shell parietes.

\begin{tabular}{|c|c|}
\hline Subgroup and characters & Species included \\
\hline \multicolumn{2}{|l|}{ challengeri subgroup } \\
\hline No conical spines on cirrus 1 & C. antennatus? \\
\hline \multirow[t]{6}{*}{ No basal guards on complex setae of cirrus 2} & C. dalli \\
\hline & C. challengeri \\
\hline & C. montagui \\
\hline & C. moro \\
\hline & C. sinensis \\
\hline & (Other Indian Ocean and Pacific spp.) \\
\hline \multicolumn{2}{|l|}{ fissus subgroup } \\
\hline No conical spines on cirrus 1 & C. anisopoma \\
\hline \multirow{5}{*}{ Basal guards present on complex setae on cirrus 2} & C. fissus \\
\hline & C. fragilis \\
\hline & C.proteus \\
\hline & C.panamensis \\
\hline & (Other tropical eastern Pacific spp.) \\
\hline \multicolumn{2}{|l|}{ stellatus subgroup } \\
\hline Conical spines present on cirrus 1 & C. angustitergum \\
\hline \multirow[t]{3}{*}{ No basal guards on complex setae of cirrus 2} & C. bisinuatus \\
\hline & C. stellatus \\
\hline & (Indian Ocean spp.) \\
\hline \multicolumn{2}{|l|}{ malayensis subgroup } \\
\hline Conical spines on cirrus 1 & C. malayensis \\
\hline Basal guards present on complex setae on cirrus 2 & C. southwardi? \\
\hline Pecten of mandible with 6 to 13 teeth & (Other Pacific and Indian Ocean spp.) \\
\hline
\end{tabular}

?, denotes species that may belong to new subgroups; entries in parentheses include species being described or not yet described.

sodium triphosphate solution, after which the cirri and trophi could be dissected and mounted in glycerine jelly. Large numbers of slide preparations of Chthamalus made by the authors since 1956 were re-examined to compare with the types. Additional new material from the tropical coast of Australia, Indonesia, Hong Kong, Taiwan and the islands of the western Pacific was dissected and mounted. Photomicrographs were taken at various magnifications under Köhler illumination, and also with phase and anoptral contrast. Photography is important in this context since many of the smallest features of the spines and setae on the cirri are close to the limits of resolution of the light microscope and drawings can show personal bias. It was not possible to prepare the type material for electron microscopy.

\section{RESULTS}

Chthamalus malayensis is reviewed first since this is the critical species. Then Chthamalus moro is considered. Features of Chthamalus challengeri, with which C. malayensis has often been confused, are also described. Table 2 lists the localities investigated, including material dissected by the authors and published descriptions that have been corrected by comparison with the type specimens.

\section{Chthamalus malayensis}

Synonymy

Chthamalus malayensis Pilsbry, 1916, pp. 310-311

Chthamalus stellatus Hoek, 1913, pp. 267-269

Chthamalus challengeri Broch, 1931, pp. 53-55; 1947, p. 5

Chthamalus malayensis Hiro, 1939, pp. 249-251
Chthamalus malayensis Utinomi, 1954, p. 18 (including C.moro) Chthamalus malayensis Karande \& Palekar, 1963, p. 231

Chthamalusmalayensis Pope, 1965, pp. 51-63 (including C.moro in part)

Chthamalus stellatus Rossel, 1972, pp. 172-174

Chthamalus antennatus Rossel, 1972, pp. 174-178

Chthamalus malayensis Newman \& Ross, 1976, p. 42

(including C. moro, following Hiro, 1939, pp. 249-251)

Chthamalus malayensis Dong et al., 1980, p. 125

Chthamalus malayensis Ren, 1984, pp. 151-153

Chthamalus malayensis Southward et al., 1998, p. 123

Chthamalus moro Poltarukha, 2001b, pp. 160-163

nec Chthamalus malayensis Nilsson-Cantell, 1938, p. 31 (= 'challengeri' subgroup)

nec Chthamalus malayensis Stubbings, 1961, p. 172 (='challengeri' subgroup)

nec Chthamalus moro Karande \& Palekar, 1963, p. 231 (used as synonym of $C$. malayensis)

nec Chthamalus malayensis Poltarukha, 2001b, pp. 157-160

(= 'challengeri' subgroup)

\section{Material examined}

NMNH type: Chthamalus malayensis (catalogue no. 48084). ANSP type: uncatalogued slide of dissected cirri and trophi, prepared by Pilsbry (1916).

ZMC type: Chthamalus challengerikrakatauensis (Broch, 1931). Specimens from Thailand, Singapore, Indonesia, Taiwan, Vietnam, Australia, Somalia, Tanzania, Kenya and Madagascar that we have studied and dissected can be attributed to this species.

Chthamalus malayensis was originally described by Pilsbry (1916) from material collected by E. Deschamps and 
Table 2. Distribution of certain Indo-west Pacific species of Chthamalus (sensu stricto) based on re-examination of types and new samples, also reassessment of published accounts. The cf. 'challengeri' column refers to specimens that lack the cirral characters of Chthamalus malayensis, and which occur outside the expected range for a temperate/warm temperate species such as $\mathrm{C}$. challengeri.

\begin{tabular}{|c|c|c|c|c|c|c|}
\hline Locality & C. malayensis & C. moro & C. challengeri & $\begin{array}{c}\text { cf. } \\
\text { "challengeri" }\end{array}$ & Reference & $\begin{array}{l}\text { Seen by } \\
\text { authors }\end{array}$ \\
\hline Korea & no & no & yes $(1)$ & no & $\begin{array}{l}\text { Kim, 1985, Kim \& Kim, } \\
\quad 1980\end{array}$ & \\
\hline Yellow Sea & yes & no & yes & no & Dong et al., 1980 & \\
\hline Japan, main islands & no & no & yes $(1)$ & no & Utinomi, 1962, 1970 & yes \\
\hline Tokara-Ryukyu Islands & yes & yes & no & no & Utinomi, 1954 & \\
\hline East China Sea & yes & yes & yes & no & Dong et al., 1980 & \\
\hline Xisha Is., S. China Sea & yes & yes & no & $(2)$ & Ren, 1984 & \\
\hline Philippines & yes & yes & no & & Pilsbry, 1916 & yes $(6)$ \\
\hline Philippines & no & yes & no & no & Broch, 1922 (in part) & in part \\
\hline Philippines & as $C$. antennatus & yes & no & no & Rossel, 1972 & \\
\hline Philippines & yes & yes & no & $?$ & unpubl. T. Yamaguchi & yes \\
\hline Palau Islands & no & yes & no & ? & Hiro, 1937 & \\
\hline Mariana Islands & no & yes? & no & ? & unpubl. A.J.S. \& W.A.N. & yes \\
\hline Truk, Caroline Islands & no & no & no & yes & unpubl. A.J.S. \& W.A.N. & yes \\
\hline Pohnpei & no & no & no & yes & unpubl. A.J.S. \& W.A.N. & yes \\
\hline Formosa (Taiwan) & yes & yes & no & $?$ & Hiro, 1939 & \\
\hline Taiwan & yes & yes & no & no & unpubl. A.J.S. \& W.A.N. & yes \\
\hline Hong Kong & yes & no & no & $?$ & $\mathrm{Wu}, 1975$ & \\
\hline Hong Kong & yes & no & no & yes & unpubl. A.J.S. \& W.A.N. & yes \\
\hline Vietnam & yes & no & no & yes & unpubl. A.J.S. \& W.A.N. & yes \\
\hline Vietnam & as C. moro & no & no & as C.malayensis & Poltarukha, 2000, 2001 & \\
\hline Ternate, Moluccas & ? & yes & no & ? & Senckenberg Museum (3) & yes \\
\hline 'Indo-China' & as $C$. challengeri & $?$ & no & ? & Broch, 1947 & \\
\hline 'Malay Peninsula' & yes & no & no & ? & Pilsbry, 1916 & yes $(5)$ \\
\hline Indonesia & as $C$. stellatus & no & no & $?$ & Hoek, 1913 & \\
\hline Indonesia & as $C$. challengeri & no & no & $?$ & Broch, 1931 & yes \\
\hline Indonesia & $?$ & no & no & as C. moro & Nilsson-Cantell, 1934 & \\
\hline Indonesia & yes & no & no & ? & Pope, 1965 & \\
\hline Indonesia & yes & yes & no & ? & unpubl. T. Yamaguchi & some \\
\hline American Samoa & no & yes & no & yes & unpubl. A.J.S. (7) & yes \\
\hline Fiji & no & yes & no & yes & Pope, 1965 & yes \\
\hline Fiji & no & yes & no & yes & unpubl. A.J.S. (7) & yes \\
\hline Tropical Australia & yes & no & no & $?$ & Pope, 1965 & some \\
\hline NW Australia & yes $(5)$ & no & no & ? & unpubl. A.J.S. & yes \\
\hline 'Burma' & no & no & no & ? & Nilsson-Cantell, 1938 & \\
\hline India, Bombay & yes & no & no & no & Karande \& Palekar, 1963 & \\
\hline India, Tranquebar & yes & no & no & no & $\begin{array}{l}\text { Dhandapani \& Fernando, } \\
1994\end{array}$ & \\
\hline Sri Lanka & ? & no & no & as $C$. challengeri & Nilsson-Cantell, 1938 & \\
\hline Pakistan, Karachi & ? & no & no & yes & unpubl. A.J.S. \& W.A.N. & yes \\
\hline Persian Gulf & no & no & no & as C.malayensis & Stubbings, 1961 & \\
\hline Bahrain & no & no & no & yes & unpubl. A.J.S. \& W.A.N. & yes \\
\hline Red Sea & no & no & no & yes & unpubl. A.J.S. \& W.A.N. & yes \\
\hline Sinai, Red Sea & no & no & no & C. barnesi & Achituv \& Safriel, 1980 & \\
\hline Southern Red Sea & no & no & no & as $C$. stellatus & Stubbings, 1936 & \\
\hline Somalia & yes & no & no & yes & unpubl. A.J.S. \& W.A.N. & yes \\
\hline Tanzania, Dar es Salaam & yes & no & no & ? & unpubl. A.J.S. \& W.A.N. & yes \\
\hline Kenya, Shimoni & yes & no & no & ? & unpubl. A.J.S. \& W.A.N. & yes \\
\hline Kenya, Mombasa & no & no & no & yes & unpubl. A.J.S. \& W.A.N. & yes \\
\hline Madagascar & probably & no & no & yes & unpubl. A.J.S. \& W.A.N. & yes \\
\hline
\end{tabular}

(1) Chthamalus dalli also present in Korea and northern Japan (Hokkaido); (2) Ren records Chthamalus antennatus and C. sinensis from mainland China; (3) collected 1894 by W. Kükenthal; (4) as Chthamalus challengeri krakatauensis; (5) tropical Australia may have other species of the 'malayensis' subgroup; (6) type specimens; (7) recent samples supplied by S.L. Coles and G. Paulay. ?, denotes published descriptions were inadequate or samples examined were too small to be sure if the species was present.

labelled only as 'from the Malay Peninsula'. Judging from the political situation in south-east Asia in the late 19th Century, the sample is likely to have come from northern Malaya, close to Indo-China. Pilsbry illustrated the mandible and maxillule (first maxilla), as reproduced in Figure 3A,D herein. He did not report conical spines on cirrus 1 and said that the setae on the terminal segments of cirrus 2 were 'as described and figured for C. stellatus' 

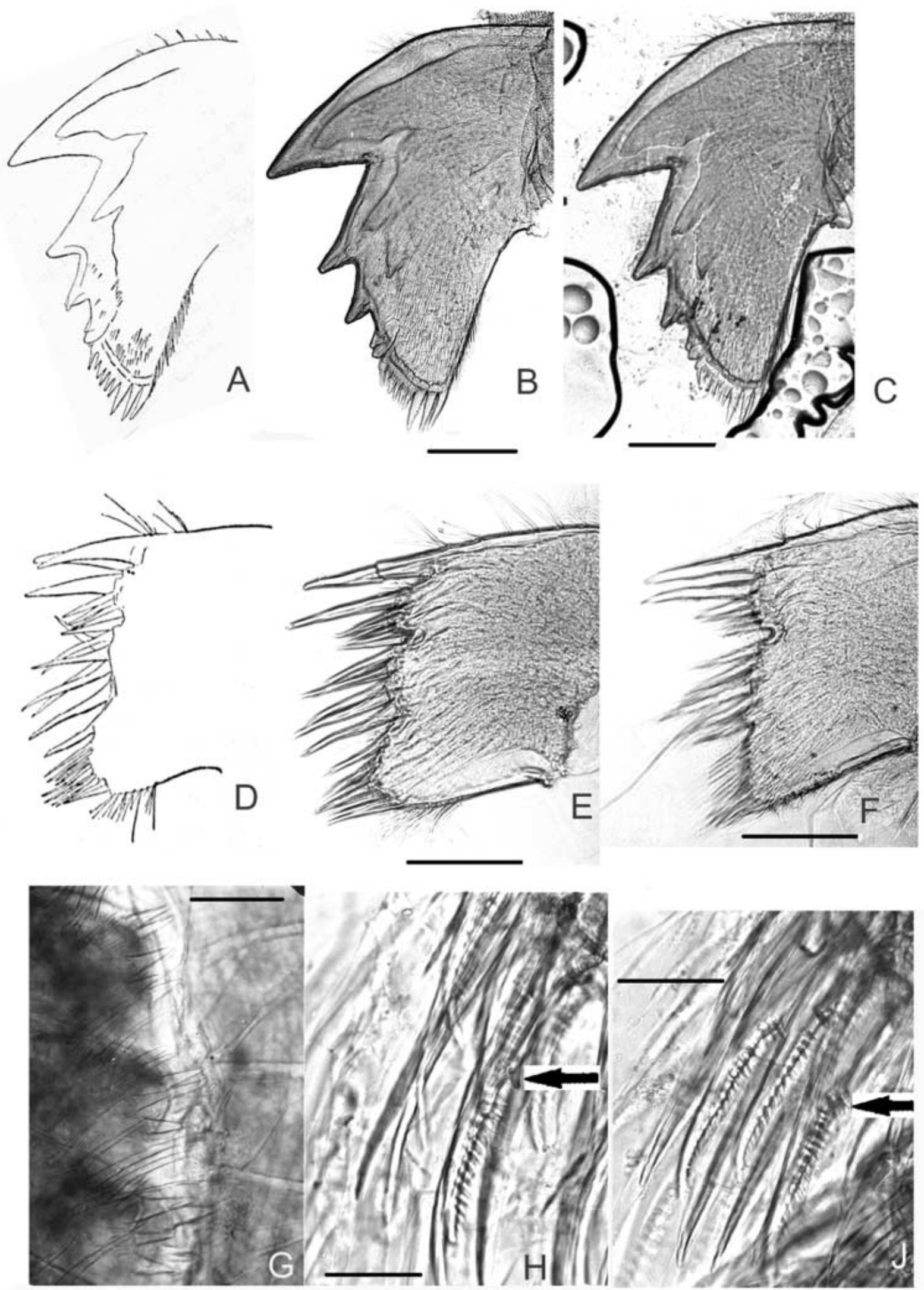

Figure 3. Chthamalus malayensis, type material. (A) Copy of the drawing of the mandible in Pilsbry (1916); (B) a mandible on the slide prepared by Pilsbry, with background blemishes brushed out; $(\mathrm{C})$ unretouched photograph of the other mandible showing background blemishes, including bubbles in the mount and some of the original hard gelatine; (D) maxillule (maxilla) drawn by Pilsbry; (E) photo of the damaged maxillule illustrated by Pilsbry; (F) the undamaged other maxillule on the type slide; (G) conical spines on the inner side of the outer ramus of cirrus 1 of the type slide; $(\mathrm{H} \& \mathrm{~J})$ the serrate setae on the outer segments of the two rami of cirrus 2 of the type slide; the arrows point to the basal guards. Scale bars: B, C, E \& F, $100 \mu \mathrm{m} ; \mathrm{G}, \mathrm{H} \& \mathrm{~J}, 50 \mu \mathrm{m}$. Note that the type slide bears only the cirri from one side of the specimen, whereas both pairs of mandibles and maxillules are included. 
and that there were 'no large-toothed spines as in C. challengeri' These comparisons are mistaken. Pilsbry's (1916) redescription of C. stellatus included both C. stellatus and C. montagui (Southward, 1976) and his redescription of C. challengeri included specimens that had serrate setae with basal guards on cirrus 2. As reported on p. 7 of this article, correctly identified $C$. challengeri have pectinate setae without basal guards on cirrus 2. Pope (1965) reviewed the morphology of C. malayensis in detail and criticized the illustrations by Pilsbry (1916) but was unable to check fully on the arthropodal features, since the slide of Pilsbry's type specimen was then missing.

The now rediscovered and rehydrated dissections of Pilsbry show the mandible to be as drawn (Pilsbry, 1916, p. 311, figure 90). There is a relatively short pecten or comb of six small teeth between the fourth large tooth and the group of teeth at the lower angle (Figure 3B,C herein). The drawing of the maxillule by Pilsbry (Figure 3D) was based on a damaged appendage that is still on the slide (Figure 3E). However, the maxillule from the other side of the mouth (Figure $3 \mathrm{~F}$ ) is also on the type slide and is similar to those sketched by Pope (1965) for Australian specimens. The undamaged maxillule does not have small spines in the U-shaped pit or notch between the upper and lower clusters of spines; these differences are not a result of normal slight asymmetry of appendages, but of damage during dissection. Inspection at high magnification shows cirrus 1 to have stout conical spines (not mentioned by Pilsbry) on the inner side of the anterior ramus, but these are not easy to see (Figure $3 \mathrm{G}$ ). The terminal segments of both rami of cirrus 2 have some coarsely serrate setae, with basal guards, in addition to some finer pectinate setae without basal guards (Figure $3 \mathrm{H} \& \mathrm{~J}$ ). These details of cirri 1 and 2 agree with the anatomy of the Australian specimens attributed to C. malayensis by Pope (1965). Several lots of Chthamalus that we have examined from Hong Kong, Taiwan, Vietnam, Indonesia and localities in Australia and around the Indian Ocean have similar features of the first and second cirri and we have classed them as C. malayensis (Table 2). Figure 4A shows a coarsely serrate seta from a Vietnam specimen that clearly illustrates the character and the basal guards; in comparison, Figure $4 \mathrm{~B}$ shows the simple pectinate setae of $C$. moro. Our data for the types and other specimens of $C$. malayensis do not agree with the characters attributed to the species by Poltarukha (2001b, pp. 157-160).

From the illustrations and description by Hoek (1913, pp. 267-269) it is practically certain the C. stellatus he recorded from Lombok, Indonesia, was $C$. malayensis. Specimens from Krakatau, Indonesia, loaned by the ZMC, and described by Broch (1931, pp. 53-55) as C. challengeri krakatauensis are in fact C. malayensis. Furthermore, it seems highly likely that $C$. challengeri challengeri reported by Broch (1947) from Indo-China is also C. malayensis. The identity of the Broch (1931) material with C. malayensis was suggested by Utinomi (1939, p. 249) as noted by Karande \& Palekar (1963, p. 231). Pope (1965)
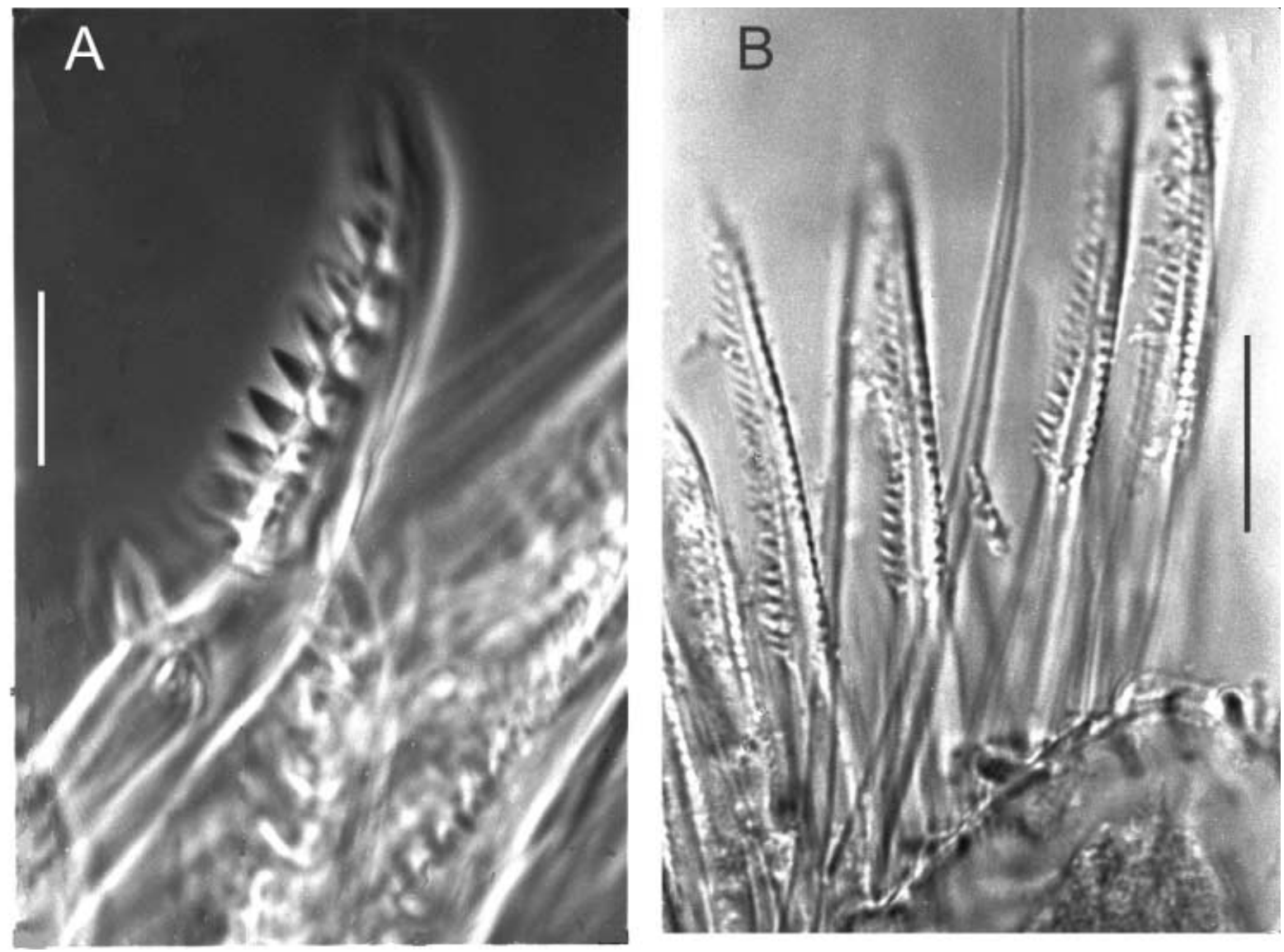

Figure 4. Complex setae of cirrus 2. (A) Chthamalus malayensis, specimen from Vietnam showing very coarse serrations and the basal guards, phase contrast objective $\times 40$, ocular $\times 16$; (B) Chthamalus moro, paratype from Zamboanga, Philippines, showing fine pectinations and absence of basal guards, apochromatic objective $\times 45$, ocular $\times 16$. Scale bars: $10 \mu \mathrm{m}$. 
agreed, and discussed problems arising from the erroneous re-description of C. challengeri by Pilsbry (1916), reported upon further below.

We confirm that the dissected type material has distinctive mandibles, one as illustrated by Pilsbry (1916), with a short pecten of six small teeth between the fourth tooth and the lower angle, the other with a pecten of ten small teeth. We therefore examined the mandibles of slidemounted dissections of many specimens that showed the features of the first and second cirri attributable to C. malayensis. As shown in Figure $5 \mathrm{~A}-\mathrm{J}$, these specimens had a relatively short pecten of up to 13 comb-like teeth, and almost all of them had three strong teeth at the lower angle. Sometimes the second and third teeth at the lower angle are partly joined at the insertion. In contrast, all the specimens showing 'challengeri' characters of the first and second cirri had a mandible with a long pecten of 20 or more small teeth and carried only one, or sometimes two, relatively small teeth at the lower angle (Figure 6A-C). The mandible thus offers a further useful distinguishing character.

An additional character was noted by Rossel (1972). He found prominent spines along the anterior ramus of cirrus 2 in specimens identified as Chthamalus antennatus Darwin 1854 and C. stellatus (Poli, 1791). The other cirral characters mentioned by Rossel indicate these specimens were probably C. malayensis as redefined here. Such spines on cirrus 2 have been found on other examples of $C$. malayensis, as shown in Figure $7 \mathrm{~B}$, but are not always easy to see. Figure 7A shows for comparison the spines on the outer ramus of cirrus 1 of a specimen of $C$. malayensis.

The placing of Chthamalus moro as a synonym of C. malayensis by several authors (Utinomi, 1954; Karande \& Palekar, 1963; Pope, 1965; Newman \& Ross, 1976) was an error. As shown below, C. moro is a valid species.

\section{Chthamalus moro}

Synonymy

Chthamalus moro Pilsbry, 1916, pp. 311-312

Chthamalus moro Nilsson-Cantell, 1921, p. 277

Chthamalus moro Broch, 1922, p. 307 (in part)

Chthamalus moro Hiro, 1937, p. 49

Chthamalus malayensis Utinomi, 1954, pp. 18-21, in part

Chthamalus malayensis Karande \& Palekar, 1963 in part

Chthamalus malayensis Pope, 1965 in part

Chthamalus moro Rossel, 1972, pp. 178-181

Chthamalus malayensis Newman \& Ross, 1976 in part

Chthamalus moro Dong et al., 1980, p. 125

Chthamalus moro Ren, 1984, pp. 153-154

nec Chthamalus moro Broch, 1922, p. 307 in part; 1931, p. 56 (includes a euraphiid)

nec Chthamalus moro Nilsson-Cantell, 1934, p. 50 (a euraphiid)

nec Chthamalus moro Poltarukha, 2001b, pp. 160-163 (= C. malayensis)

Material examined

NMNH type: Chthamalus moro (catalogue no. 48197).

ANSP paratypes: Chthamalus moro (catalogue nos. I-6460, I-6461; Tetraclita squamosa catalogue no: I-6923).

Specimens from Taiwan, the Mariana Islands, the Caroline Islands, the Philippines, Indonesia, Fiji and Samoa that we have studied and dissected can be attributed to this species.

Pilsbry described C. moro from small dry specimens collected at Zamboanga in the southern Philippines, but did not dissect them. The dried types were attached to a shell of Tetraclita (Figure 8A). Additional dry paratype material listed by Pilsbry (1916) from the same locality, was loaned by the ANSP; these were also on shells of Tetraclita. Additional specimens from Mindoro, Philippines, on limestone, validated by Rossel, were loaned by the ZMC. The ZMC also loaned the sample from Zamboanga examined by Broch (1922, p. 307)). The latter sample contained many isolated specimens of C. moro and a group on the shell of a limpet, but also included many specimens of a euraphiid barnacle. The drawing and description of the mandible of 'C. moro' from this sample by Broch does not agree with our dissections of the type material and specimens from other locations, nor with the description by Rossel (1972), as that author realized. It seems possible that Broch was confusing the two species in the sample and illustrated the mandible of the euraphiid. Figure 8A shows the shell walls of paratypes of Pilsbry's species and Figure $8 \mathrm{~B}$ shows specimens from the type locality, complete with opercular plates, identified by Broch (1922).

The mounted appendages obtained from a rehydrated paratype confirm that $C$. moro is quite distinct from C. malayensis, since cirrus 1 lacks conical spines, and cirrus 2 carries only finely pectinate setae without basal guards (Figure 4B). The mandible has a fairly long pecten, and there are only one or two teeth at the lower angle (Figure 8G). The maxillule has only a small notch between the upper and lower larger spines, partly filled with smaller spines (Figure 8D). Rossel (1972) described the same set of arthropodal characters for the Mindoro specimens (Figure 9). These characters place C. moro in the 'challengeri' subgroup of Dando \& Southward (1980). Ren (1984) has described typical Chthamalus moro from the Xisha Islands, formerly the Paracel Islands, 170 miles south-east of Hainan Island and 300 miles west of the Philippines. As yet, there are no records for mainland China or Vietnam.

Chthamalus moro is thus not a juvenile stage of Chthamalus malayensis as stated by Utinomi (1954), Pope (1965) and Newman \& Ross (1976), but a distinct species. The small size of the specimens makes dissection difficult, and the defining characters of cirri 1 and 2 need careful searches at high magnification. In the field it should be distinguishable from C. malayensis by its smaller size and stronger ribbing of the parietes (Figure 2).

\section{Chthamalus challengeri}

\section{Synonymy}

Chthamalus challengeri Hoek, 1883, pp. 165-166

Chthamalus challengeri nipponensis Pilsbry, 1916, pp. 309-310

Chthamalus challengeri Nilsson-Cantell, 1927, p. 781

Chthamalus challengeri Dong et al., 1980, p. 125

nec Chthamalus challengeri Pilsbry, 1916, pp. 307-308

nec Chthamalus challengeri Nilsson-Cantell, 1928, pp. 280281, from Java

nec Chthamalus challengeri krakatauensis Broch, 1931, pp. 53-55 nec Chthamalus challengeri Nilsson-Cantell, 1938, p. 31 nec Chthamalus challengeri challengeri Broch, 1947, p. 5 

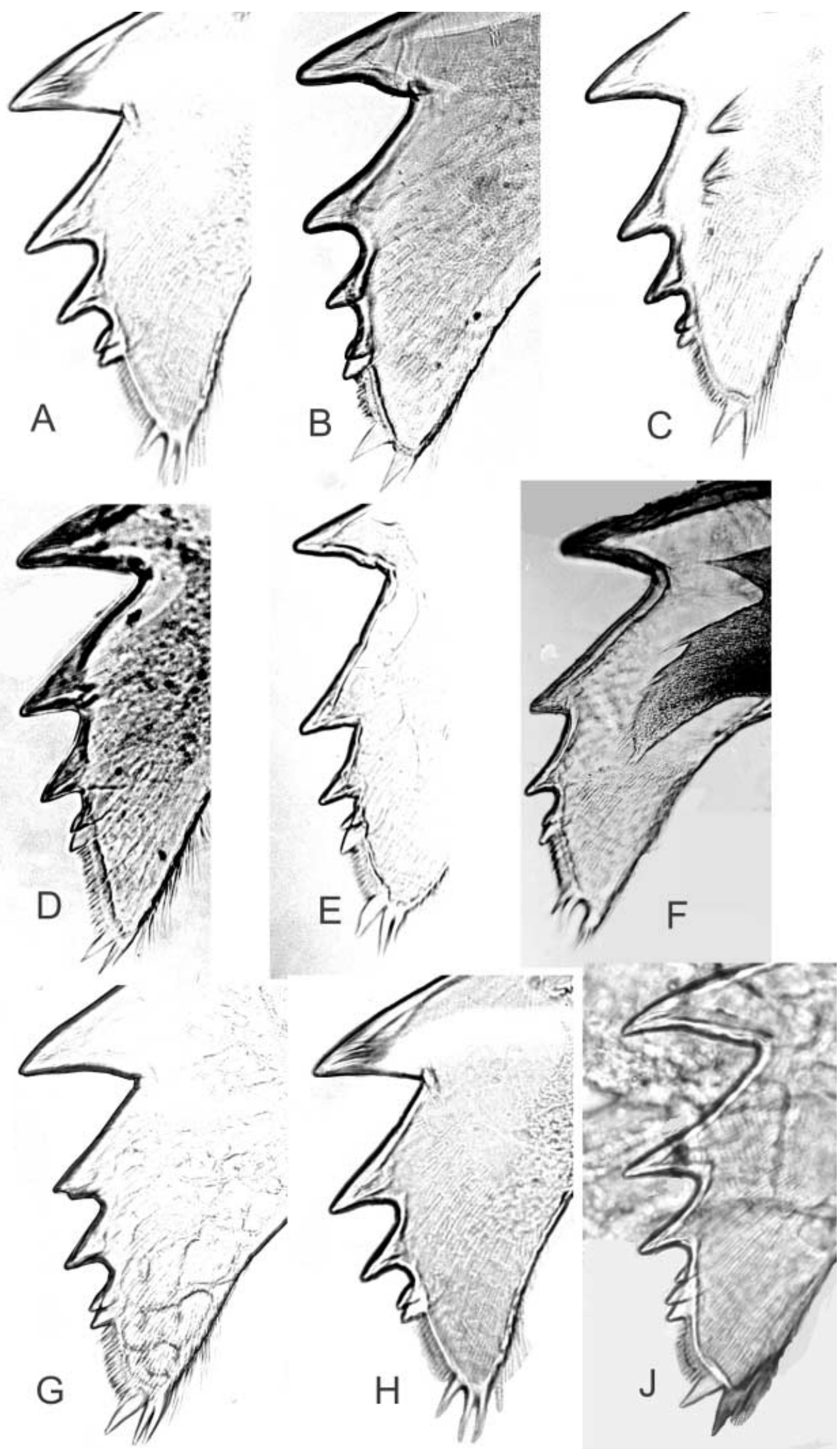

Figure 5. Chthamalus malayensis. Comparison of the inner edge of the mandibles of specimens from different locations, all enlarged to approximately the same size. (A) Hong Kong; (B) Vietnam; (C) north coast of Western Australia; (D) Somalia; (E) Somalia; (F) Somalia; (G) Tanzania; (H) Kenya; (J) Kenya. Note that the pecten is short in all, but that the teeth at the lower angle show variation in prominence of the third tooth. 

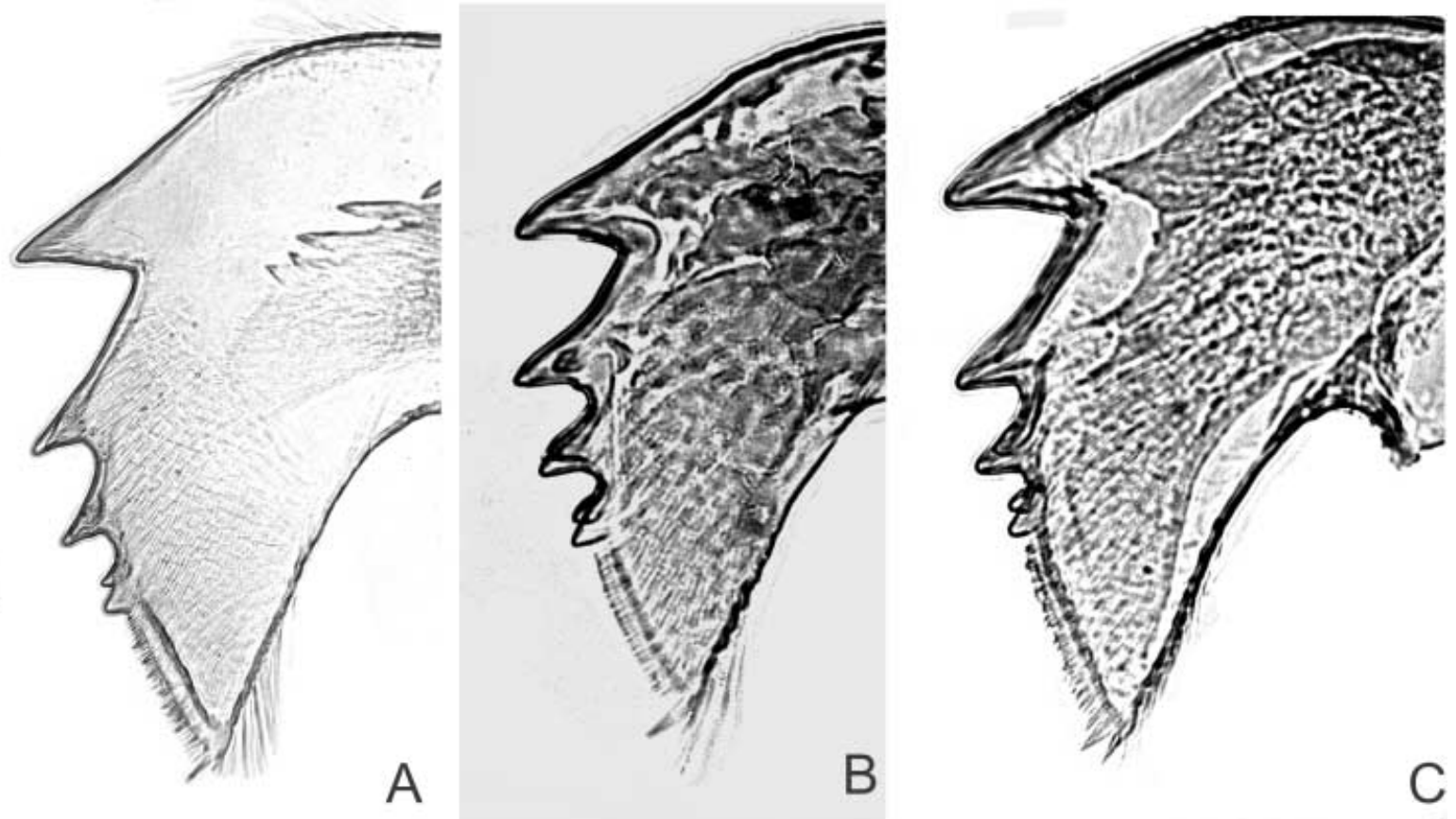

Figure 6. Mandibles of the 'challengeri' subgroup. (A) Chthamalus challengeri (sensu stricto) from Tanabe Bay, Japan, collected by H. Utinomi; (B) 'challengeri' form from Nimitz Beach, Guam, Mariana Islands (= C. moro); (C) undescribed 'challengeri' form from Indian Ocean coast of Oman. All enlarged to approximately the same size. The pecten is longer than in C. malayensis and there are fewer and smaller teeth at the lower angle.

\section{Material examined}

Natural History Museum, London (types of Chthamalus challengeri Hoek).

Specimens from Japan supplied by H. Utinomi and T. Yamaguchi.
A basic problem for anyone studying Indo-west Pacific chthamalids is that the re-description of $C$. challengeri by Pilsbry does not agree with the type specimens or the abundant species of Chthamalus found on Japanese shores. The type material consists of a group of juveniles that
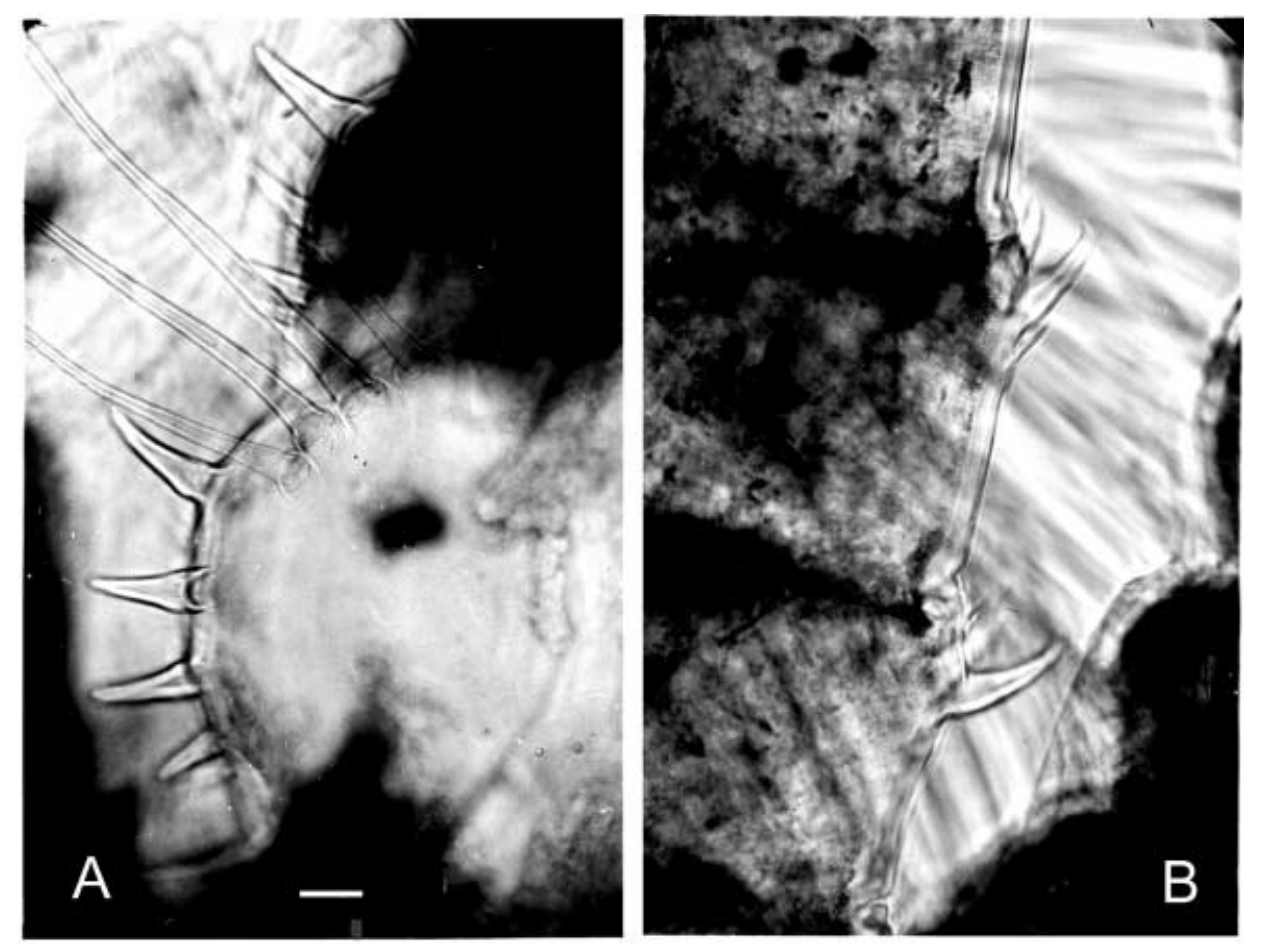

Figure 7. Spines on the first (A) and second (B) cirri of Chthamalus malayensis, to the same magnification. Specimens from Vietnam. Objective $\times 40$, eyepiece $\times 6.3$, Köhler illumination. Scale bar: $20 \mu \mathrm{m}$. 

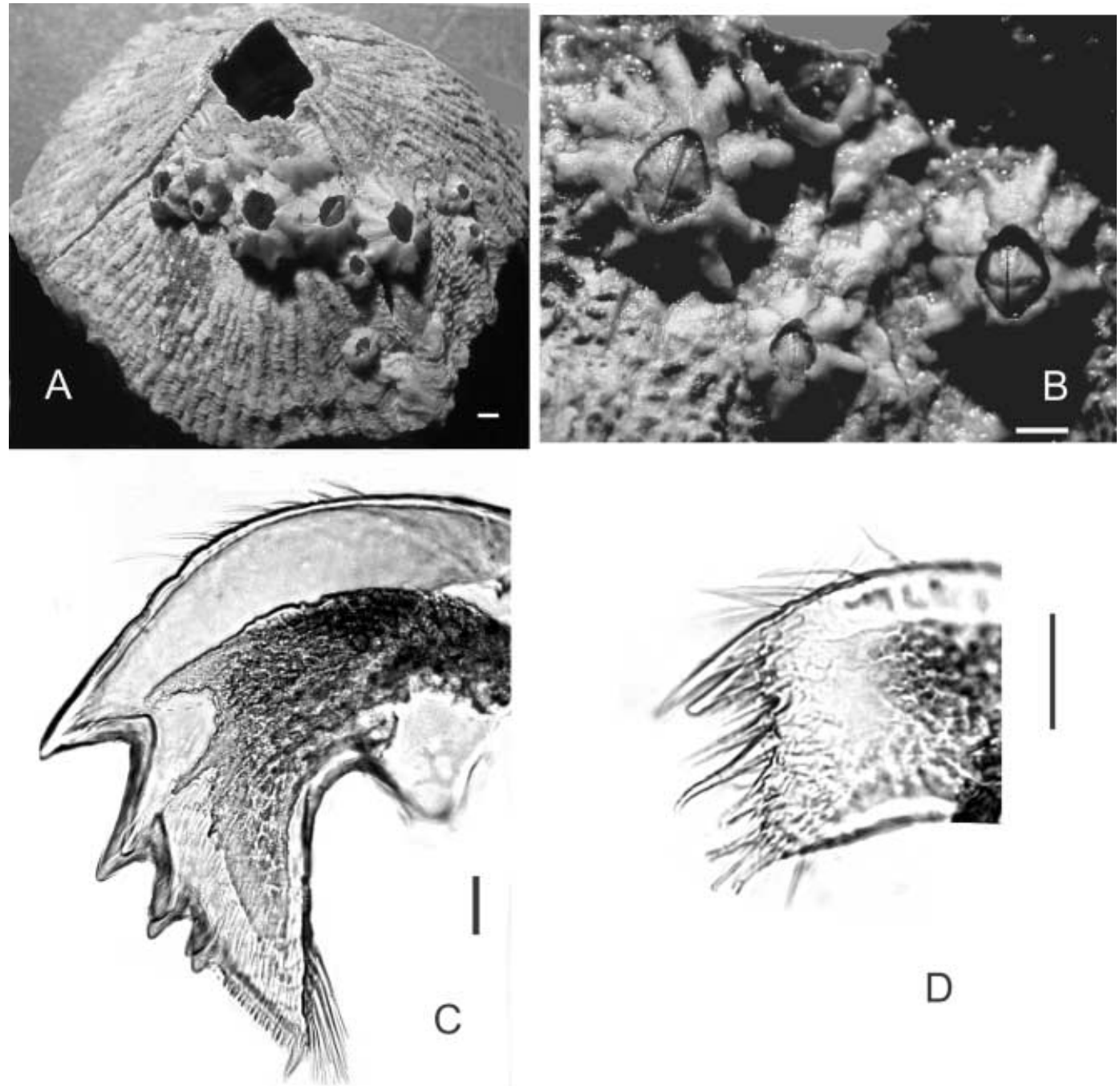

D

Figure 8. Chthamalus moro. (A) The paratypes in the NMNH from which Pilsbry had selected three sets of opercular plates to mount on black card (see Figure 10B), on a shell of Tetraclita; (B) ethanol-preserved examples of the species from the type locality, Zamboanga, on a limpet shell collected by Th. Mortensen in 1914, identified by H. Broch, 1921, ZMC; (C) mandible of rehydrated paratype from ANSP; (D) maxillule of rehydrated paratype from ANSP. Scale bars: A \& B, $1 \mathrm{~mm}$; C \& D, $20 \mu \mathrm{m}$.

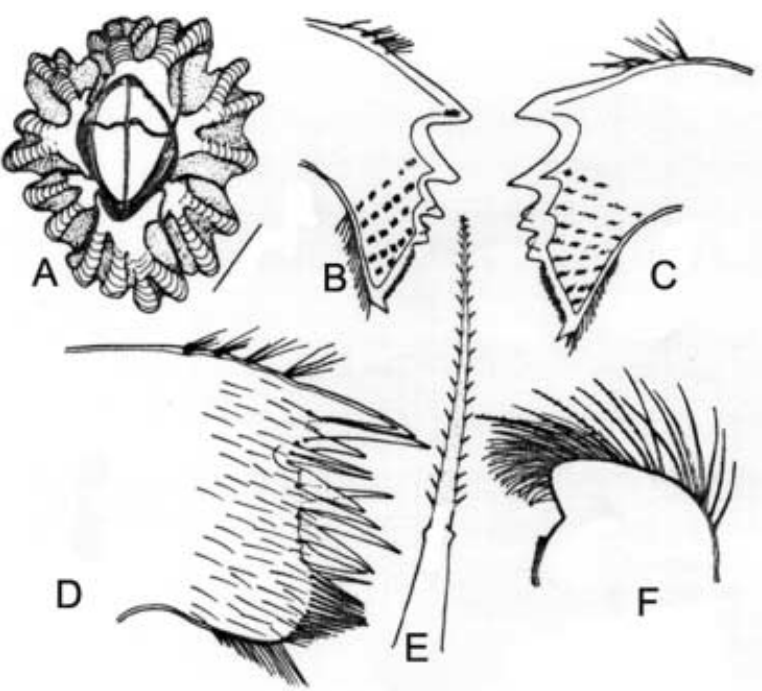

Figure 9. Features of Chthamalus moro as illustrated by Rossel (1972) from specimens collected in Mindoro, Philippines. (A) Whole animal; (B \& C) mandibles; (D) maxillule; (E) pectinate seta from cirrus 2; (F) maxilla. Scale bar: A, $1 \mathrm{~mm}$. were scraped from the screw of HMS 'Challenger' following some weeks in Japanese waters (Hoek, 1883). Many years ago one of us (A.J.S.) examined the types in London and more recently we looked at several lots of Japanese Chthamalus sent to us by the late H. Utinomi (formerly F. Hiro) and by T. Yamaguchi. These all show the same characters of the appendages: no conical spines on cirrus 1 and finely pectinate setae without basal guards on cirrus 2. A mandible of $C$. challengeri (sensu stricto) from Japan is shown in Figure 6A.

In contrast, Pilsbry (1916, p. 307) describes a specimen from Matsushima as having on the posterior border of the anterior ramus of cirrus 1 'some very short, stout, slightly curving spines, much as figured for $C$. cirratus, but not noticed in any other species'. He also says the terminal segments of both rami of cirrus 2 have 'several simply serrate spines and a few broad ones with two coarse teeth below the finely serrate portion'. These are characters shown by C. malayensis, as stated above, but there are no records of $C$. malayensis from the main Japanese Islands (Utinomi, 1970). This sample is recorded as collected at Matsushima, which is a very landlocked bay north of 

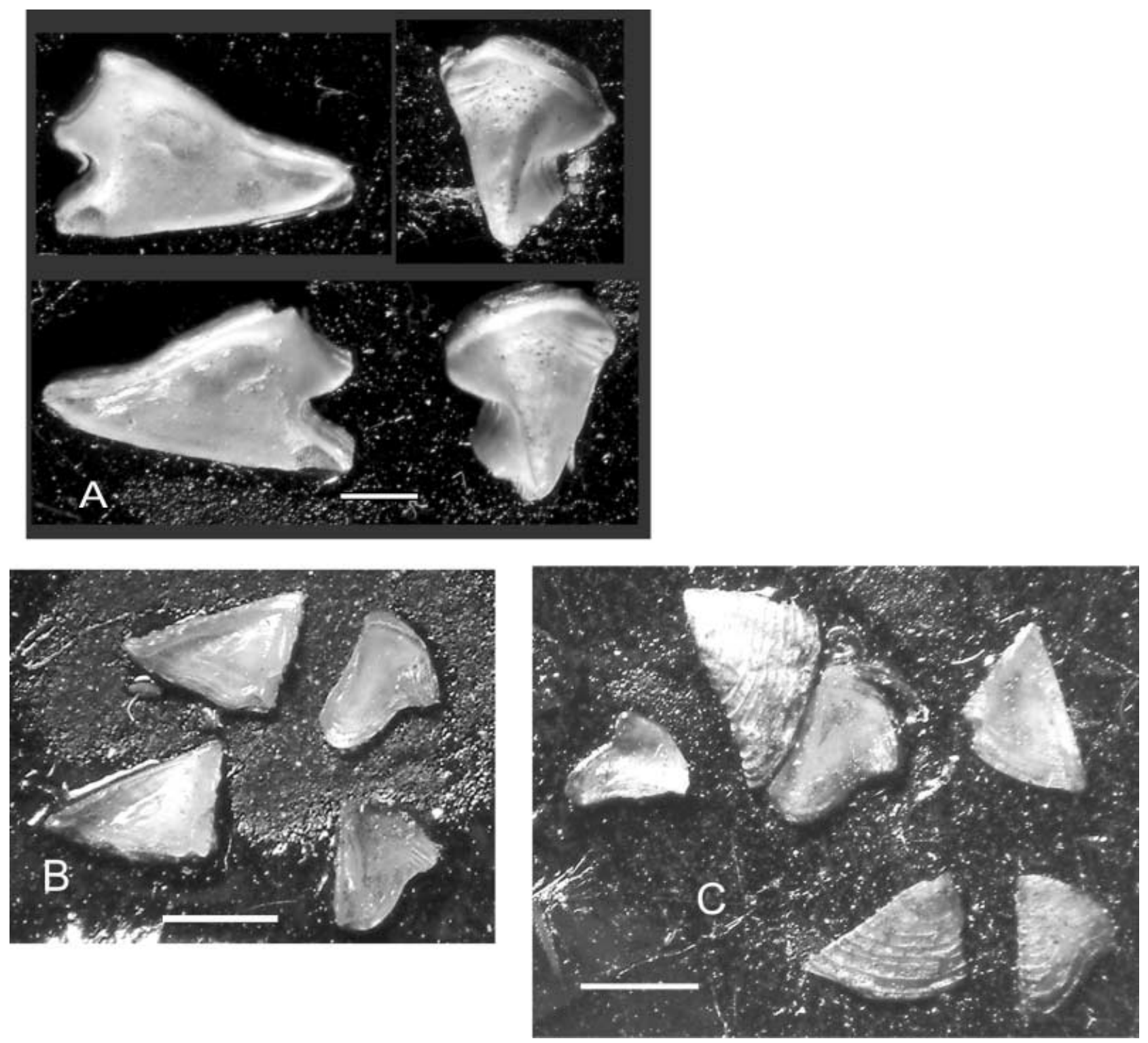

Figure 10. (A) Inner side of opercular plates of Chthamalus malayensis, Pilsbry's type preparation; (B) inner side of opercular plates of Chthamalus moro, Pilsbry's type preparation; (C) other opercular plates of C. moro, some showing outer surface, on the same slip as $\mathrm{B}$, selected by Pilsbry. These opercular plates are stuck to slips of black card with strong glue, but differences between the species in the shape of the tergum and of the tergo-scutal articulation are easy to see (see text). Scale bars: $1 \mathrm{~mm}$.

Tokyo. The description certainly does not fit the types of C. challengeri and it seems possible we have a mislabelling problem. Pilsbry also mentions and illustrates a group of C. challengeri from Yokohama, which is where HMS 'Challenger' spent some time, but he did not report on the appendages and mouthparts. He also notes specimens from Ayukawa that have no pectinate setae on cirrus 2, but does not mention cirrus 1 . There are at least two places named Ayukawa in Japan. One is a fishing port in Hokkaido, where Chthamalus dalli might be expected to occur as well as C. challengeri, while another Ayukawa exists on the Japan Sea coast of middle Honshu.

It is difficult to believe these strong differences reported by Pilsbry (1916) from Japanese material could be shown by a single species, and hence he must have been working with more than one species, as apparently happened when he described Chthamalus from tropical Atlantic and Caribbean sites (Dando \& Southward, 1980).
In describing a new subspecies, C. challengeri nipponensis, from an unreported location in Japan, Pilsbry (1916, p. 309) does not mention any stout spines on cirrus 1 and says that the terminal segments of cirrus 2 have 'several serrate spines....but these spines have not the large lower teeth seen in C. challengeri. We have seen that this report of basal guards in C. challengeri is erroneous. In effect Pilsbry's subspecies nipponensis corresponds better to the types of $C$. challengeri than his redescription of the species itself.

Nilsson-Cantell (1921) identified museum material from Japan and Java as belonging to Chthamalus challengeri, but did not report whether there were conical spines on cirrus 1. For cirrus 2 he notes pectinate setae in both samples, those from Java being strong and those from Japan being weak; we interpret this as the Java specimens being C. malayensis with serrate setae, and the Japanese specimens being $C$. challengeri with pectinate setae. 


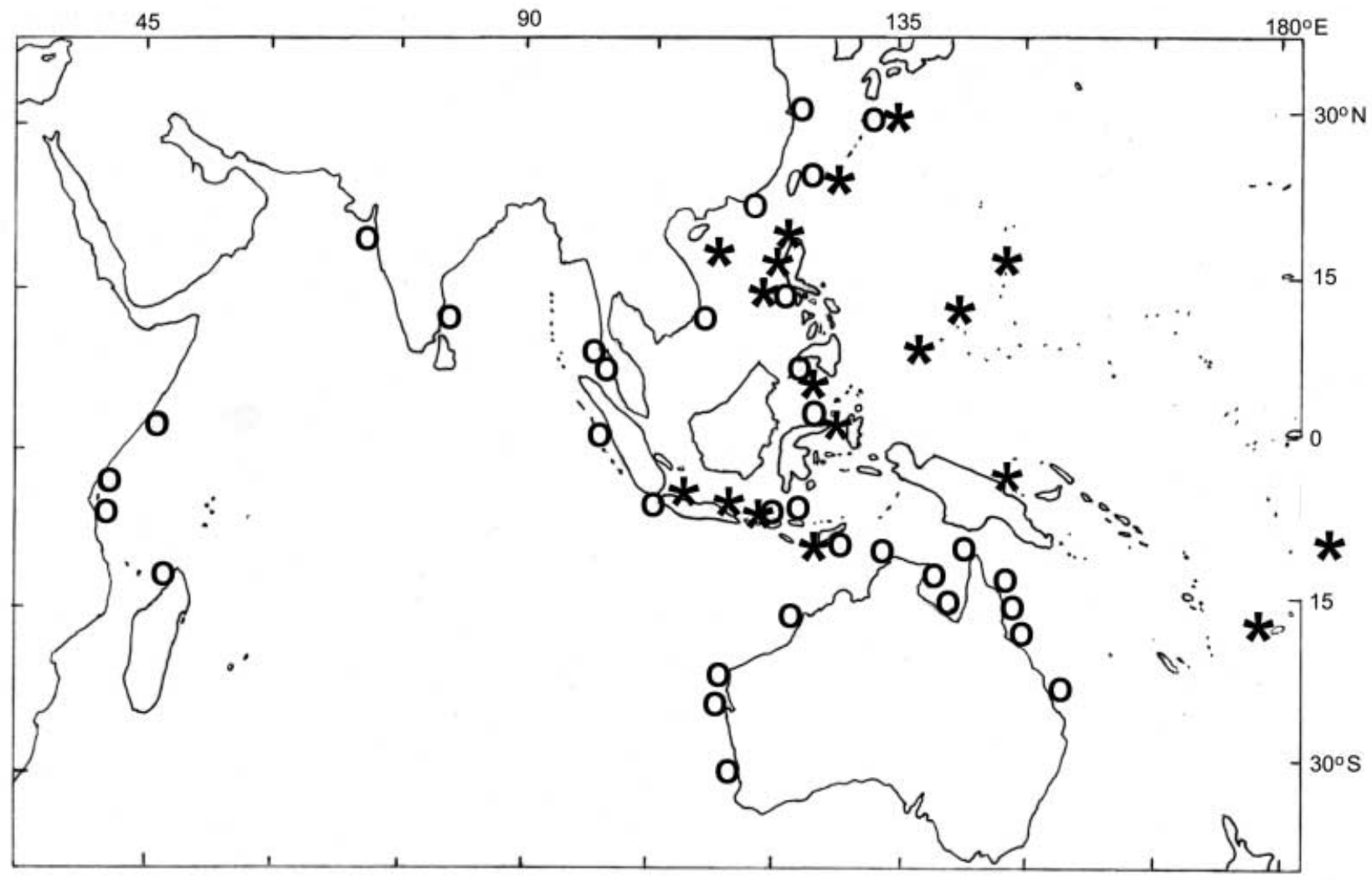

Figure 11. Outline map of the Indo-Malayan region and the western Pacific, from $35^{\circ} \mathrm{N} 35^{\circ} \mathrm{E}$ to $35^{\circ} \mathrm{S} 180^{\circ} \mathrm{E}$, showing locations where Chthamalus malayensis occurs (open circles) and where Chthamalus moro has been correctly recorded (asterisks). The published record by Pope (1965) of C. malayensis in Fiji is suspect as three expeditions there since 1986 have failed to find it, and the deposited samples in the Australian Museum are not C. malayensis. At least one undescribed species of Chthamalus belonging to the 'challengeri' subgroup is also present in the regions mapped. The record of C. moro at the eastern end of the map refers to American Samoa.

\section{DISCUSSION}

\section{Erroneous descriptions}

The erroneous or only partial descriptions of the 'arthropodal' characters of the oriental species of Chthamalus by Pilsbry (1916), has caused much confusion in several later accounts of cirripede collections from the Indo-west Pacific. It has already been mentioned that Broch's $(1931,1947)$ records of $C$. challengeri are likely to be referable to C. malayensis. The record of $C$. malayensis from Taiwan (as Formosa, in Hiro, 1939) does not mention spines on cirrus 1 or serrate setae on cirrus 2, but specimens from Patoutzu, Keelung, sent to us recently are indeed C. malayensis. There are several records of C. malayensis from the Indian Ocean, not all of which are based on distinctive arthropodal characters. The descriptions of Nilsson-Cantell (1938) and Stubbings (1961) provide enough detail to show that their specimens were not in fact C. malayensis. The specimens described from Mindoro, Philippines as C. stellatus and C. antennatus by Rosell (1972) are probably C. malayensis. Chthamalus malayensis has also been reported from Hong Kong and the Chinese mainland, and we can confirm the former.

Records of $C$. moro other than from Indonesia, the Philippines, Taiwan and the Xisha Islands need scrutiny. The report of this species from Palau (Hiro, 1937), some 480 miles east of the Philippines, may well be correct, since no mention is made of conical spines on cirrus 1 and cirrus 2 is said to have pectinate setae. However, the occurrence on 'twigs' needs noting, since the original record by Pilsbry is from occurrences on intertidal specimens of Tetraclita. We have recently seen specimens of C. moro from the Mariana Islands, the Caroline Islands, Fiji and Samoa but not the Malay Peninsula. Broch (1922, 1931) reports C. moro on mangrove roots and leaves of Avicennia in Siam, but gives no details of morphology. This is a habitat more likely to be occupied by euraphiid barnacles. We have examined some of Broch's specimens and they do resemble Microeuraphia, a genus erected by Poltarukha, 1997 in his revision of the genus Euraphia. The specimens from Vietnam that Poltarukha (200la,b) described as C. moro are attributable to C. malayensis on the basis of the arthropodal characters shown by the type. Our samples from Vietnam did not contain C. moro and we have not seen it in samples from Hong Kong.

Some authors have described Chthamalus stellatus from the Indian Ocean. In theory C. malayensis might possibly be mistaken for $C$. stellatus (Poli) if the basal guards on the serrate setae of the second cirrus were not easy to see. Unfortunately many authors have relied on the confused descriptions in Pilsbry (1916, pp. 301-304) of a mixture of what is now two species: C. stellatus (Poli) and C. montagui Southward, one of which has conical spines on cirrus 1 and the other does not (Southward, 1976). Daniel (1956, p. 34) described Chthamalus stellatus stellatus as common on the Madras coast, but his illustrations and text make it clear 
that he was not working with C. malayensis, more likely a 'challengeri' form. Stubbings (1936) described C. stellatus from the Red Sea, but the details he gives also suggest a 'challengeri' form. Nilsson-Cantell (1938, pp. 29-30) mistakenly lists $C$. stellatus and $C$. challengeri from the Indian Ocean. His record of C. malayensis in the same report (p. 31) says 'Cirrus II has no large-toothed spines on the terminal segments' and he must therefore have been examining a 'challengeri' form.

\section{Shell morphology}

Shell characters of the species of Chthamalus discussed here show much change with age and habitat, as do most species of the genus. However, some distinctive characters can be observed. Specimens of Chthamalus moro are not only smaller than $C$. malayensis but are usually more conical in shape and have stronger ribbing of the parietes (Figure 2).

Chthamalus malayensis looks comparatively flat and grows to a larger size, without marked ribbing. However, there may be a sinuous margin around the growing basal edge of the parietes. The outer surface of large specimens usually shows considerable erosion, comparable to that seen in C. stellatus.

Figure 10 shows the card-mounted terga and scuta prepared by Pilsbry from the holotypes. His descriptions are worth quoting:

Chthamalus malayensis 'The opercular valves are deeply corroded externally, nearly white within, punctate. The articular ridge of the scutum is very prominent in the middle, tapering both above and below. Adductor pit rather deep, and there is a very small rudiment of an adductor ridge. The tergum is triangular, very narrow at the lower end. Articular ridge broadly reflexed. Scutal border broadly reflexed. Basal border nearly straight.' (We agree with this except that the adductor ridge is not really so rudimentary, though small.)

Chthamalus moro 'The tergal margin of the scutum is nearly equal to the basal; articular ridge straight, long, obliquely truncate below, not projecting beyond the tergal border of the valve. Adductor muscle pit not deep. There is no adductor ridge. Pit for the lateral depressor muscle deep. Interior white. Tergum with moderately developed articular ridge and narrow articular furrow. Spur broad, rounded, and short. Carinal lobe, bearing the crests, rather large, making an angle with the rest of the basal margin. This species has valves much like those of the American C. fragilis, but the articular ridges of both valves are weaker.' (We note that the interior of the valves of the type cannot now be called white.)

Pilsbry (1916) equated the shell characters of Chthamalus moro with those of $C$. fragilis from the US Atlantic coast, and this may partly explain why later workers (Utinomi, 1954; Pope, 1965) regarded C. moro as a juvenile form of C. malayensis. Other species of the genus do indeed pass through a juvenile stage where the scutum and tergum resemble those found in adult C. fragilis and C. moro. With growth and age the muscle insertions and adductor ridges of other species become more prominent and the tergoscutal articulation becomes more sinuose.

\section{Biogeographical considerations}

\section{Chthamalus malayensis}

From the somewhat scattered records, it would seem that C. malayensis is a tropical Indo-west Pacific species that occurs widely in the Indian Ocean, in Indo-Malayan, Indonesian and Indo-Chinese waters and on tropical shores of Australia (Table 2; Figure 11). As Pope (1965) said, if the distribution of species of Chthamalus recorded by previous authors is plotted on a chart, the results resemble random shotgun patterns rather than sensible patterns related to climatic or other biogeographic factors. It is unfortunate that many previous authors appear to have relied on the old records quoted by Darwin (1854) for his then world-wide distributed species of Chthamalus to justify their species attributions, particularly records of so-called $C$. stellatus from the Indian and Pacific Oceans. Chthamalus stellatus is restricted to Europe, North Africa and the Atlantic islands of Madeira, the Azores and the Canaries (Crisp et al., 1981).

The known distribution of C. malayensis is shown in Figure 11. Occurrence north of the South China Sea and the Philippines needs verification. The species was reported by Utinomi (1954, pp. 18-21) from the Ryukyu Islands, and this seems quite likely in view of their tropical fauna. However, the published description includes characters that fit C. moro, and Utinomi probably had specimens of both species when he lumped $C$. moro as a synonym of $C$. malayensis.

Records of $C$. malayensis east of Indonesia and the Philippines require checking, especially those from some of the islands of the west Pacific. We have examined material in the Australian Museum collected in Fiji by Elizabeth Pope and Isobel Bennett. The samples do not contain C. malayensis as reported by Pope (1965) but are mostly a species of the 'challengeri' subgroup, with one example of C. moro. Foster (1974) also recorded C. malayensis from Fiji, but some of his illustrations of opercular plates differ strongly from typical C. malayensis. The only extant specimen from Foster's collection is an undescribed species belonging to the 'challengeri' subgroup. Foster (1990) also reported C. malayensis from Guam, but a sample collected by one of us (W.A.N.) there and another by G. Paulay, do not support this record. Samples from Fiji, collected by one of us (W.A.N.) and also by S.L. Coles and G. Paulay do not contain C. malayensis, but they do include C. moro and an undescribed species of the 'challengeri' subgroup. A similar mix of C. moro and an undescribed species of the 'challengeri' subgroup is found in samples from American Samoa collected by S.L. Coles and G. Paulay. Recently, we examined specimens of Chthamalus attached to the shells of the pedunculate barnacle, Capitulum mitella, on loan from the collections of the NMNH. These dated back to the late 19th Century and were Chthamalus moro.

Since Pope (1965) appears to have wrongly identified C. malayensis in Fiji, her records of the species in New Caledonia and the Santa Cruz Islands require verification.

A possible member of the 'malayensis' subgroup was recently described by Poltarukha (2000) as Chthamalus southwardi, collected in the Seychelles Islands. From the description, this species possesses the typical 'malayensis' characters of the first and second cirri, but it differs in the 
height of the tergum, which is much bigger than in C. malayensis. It also differs in the mandible, which has a long pecten, and in the maxillule, which appears to have no gap between the upper cluster of spines and the lower spines. One of us (A.J.S.) has seen chthamalids from Somalia, with a similar high tergum, collected at the same locations as C. malayensis and 'challengeri' type specimens. Although these Somali specimens have C. malayensis characters of the first cirrus and mandible, they have finely pectinate setae without basal guards on cirrus 2 . There has been no opportunity for further barnacle studies in that part of Africa. From the characters of this Somali form and from the description of $C$. southwardi it seems possible that other subgroups of Chthamalus exist in the Indo-west Pacific, additional to those listed in Table 1. It also seems probable that more species of the 'malayensis' subgroup are awaiting discovery.

\section{Chthamalus moro}

In contrast to C. malayensis, Chthamalus moro appears to have a local distribution (Table 2; Figure 11). It is present in Indonesia, the Philippines, Taiwan, the Xisha Islands, the Ryukyu Islands, Palau, the Mariana Islands, the Caroline Islands, Fiji and Samoa. It is noteworthy that in the latter two groups of islands, C. moro is mostly present on the shells of larger barnacles, including Tetraclita viridis, Tesseropora wireni and Capitulum mitella. Chthamalus moro was not found in samples from the Tuamotu group, so that Samoa is presently its eastern limit in the Pacific. There are no valid records from mainland south-east Asia or the Indian Ocean. The apparent restriction of C. moro to islands suggests that it is an old species, possibly adapted to life in harsh tropical environments, and unable to compete on the mainland with newer chthamalids such as C. malayensis.

\section{Chthamalus challengeri}

Chthamalus challengeri in the strict sense is reliably reported only from Japan, from southern Hokkaido to the Ryukyus (Utinomi, 1949, 1954, 1962, 1970) and from South Korea (Kim \& Kim, 1980; Kim, 1985) and the Yellow Sea (Dong et al., 1980). It can be assumed to be a temperate/ warm temperate species of restricted distribution. In northern and eastern Hokkaido C. challengeri is replaced by $C$. dalli, which is the species found in the cooler waters of the North Pacific, from Far Eastern Russia across to Alaska and down south to California. It is difficult to plot the distribution of Chthamalus challengeri and C. dalli from published records, since $C$. challengeri cannot be separated from $C$. dalli by purely arthropodal characters. The table given in Tarasov \& Zevina (1957) for distinguishing these two species does not work. This table states that C. challengeri has conical spines on cirrus 1 and serrate setae with basal guards on cirrus 2, which we know is a mistake, based on the erroneous re-description in Pilsbry (1916).

We have seen specimens of 'challengeri'-like forms of Chthamalus from locations in the Indian Ocean, including the Red Sea, the Persian Gulf, Somalia, Pakistan, Thailand, Vietnam and some of the islands of the western Pacific. These occurrences are to be compared with C. sinensis of Ren (1984), for which the spines of cirrus 1 are not recorded, and with C. barnesi, a 'challengeri' group species described by Achituv \& Safriel (1980) from the Sinai Peninsula in the northern Red Sea. There is probably more than one form of Chthamalus belonging to the 'challengeri' sub-group in the tropical Indo-west Pacific but further work, including genetic investigation, is needed to confirm their status and distribution.

\section{Other species}

The distribution of Chthamalus antennatus in Australia indicates it to be a temperate to warm-temperate adjusted species that has not even spread to New Zealand (Pope, 1965). Therefore the few records of this species from tropical locations in south-east Asia must be viewed with caution. The material from the Philippines attributed to C. antennatus by Rossel (1978) has characters of C. malayensis and also apparently lacks the antenniform third cirri that are usually shown by $C$. antennatus. The material described by Ren (1984) from China does possess antenniform third cirri, but in other characters it fits the 'challengeri' group. This Chinese population might represent an introduction of the Australian species to Chinese waters via shipping, or we may have to consider the possibility that other species of chthamalids can show antenniform third cirri that are not always detected (cf. Pope, 1965). Unpublished work by one of us (W.A.N.) indicates that in Tetrachthamalus oblitteratus the development of the antenniform rami of the third cirri cyclically alternates with development of the penis.

Some final points resulting from this investigation can be stated. First, conserved type material is of utmost importance to biodiversity and biogeography as well as to taxonomy. The current tendency of administrators to dispose of regional fauna collections and University museums is misguided. Secondly, the genus Chthamalus is worthy of more biochemical genetic studies, in view of its variation and on account of the influence of this variation on Darwin's thinking and the development of his ideas on evolution (Southward, 1983). Work on the Chthamalus genome is now proceeding in Europe, Israel and Japan as well as in Britain and the United States.

We are grateful to many old friends and colleagues who have in the past collected chthamalid barnacles for us during their travels or who generously allowed us to look at specimens from personal collections. For recent samples we are greatly indebted to: Diana Jones (Australia); Mark Grygier and Ping-Hung Chen (Taiwan); Benny Chan and Yan Yan (Hong Kong); Ruth O'Riordan (Singapore); Steve Coles (Fiji and American Samoa); Gustav Paulay (Fiji, American Samoa and the Tuamotus); Toshiyuki Yamaguchi (Indonesia); and Philip Rainbow (Hong Kong and Thailand). G. Chelazzi supplied the material from Somalia and John Buckeridge advised on the late Brian Foster's collection. We also thank Eve Southward for help with the microscopy, Benny Chan and Lanna Cheng for information on Chinese geography, G. Boxshall for help with material in the Natural History Museum and access to rare journals, G. Rosenberg for locating the type slide of Chthamalus malayensis and the curators at the US National Museum, Washington, the Academy of Natural Sciences, Philadelphia, the Zoological Museum, Copenhagen and the Senckenberg Museum, Frankfurt for the loan of specimens. Marco Abbiati skilfully converted the Russian text of Poltarukha (2001b) to English, Mark Grygier translated the key to Chthamalus species in Poltarukha (2000) and Alexey Elfimov provided an English version of a table in Tarasov \& Zevina (1957). 


\section{REFERENCES}

Achituv, Y. \& Safriel, U.N., 1980. A new Chthamalus (Crustacea: Cirripedia) from intertidal rocks of the Red Sea. Israel fournal of Zoology, 29, 99-109.

Broch, H., 1922. Papers from Dr Th. Mortensen's Pacific Expedition 1914-1916. X. Studies on Pacific cirripeds. Videnskabelige Meddelelser fra Dansk naturhistorisk Forening $i$ Kobenhaven, 73, 215-358.

Broch, H., 1931. Papers from Dr Th. Mortensen's Pacific Expedition 1914-1916. LVI. Indomalayan Cirripedia. Videnskabelige Meddelelser fra Dansk naturhistorisk Forening $i$ Kobenhaven, 91, 1-146.

Broch, H., 1947. Cirripedes from Indochinese shallow waters. Norsk Videnskaps-Akademi Avhandlingar, M.-N. Kl., $1947(7)$, $32 \mathrm{pp}$.

Crisp, D.J., Southward, A.J. \& Southward, E.C., 1981. On the distribution of the intertidal barnacles Chthamalus stellatus, Chthamalus montagui and Euraphia depressa. Fournal of the Marine Biological Association of the United Kingdom, 61, 359-380.

Dando, P.R., 1987. Biochemical genetics of barnacles and their taxonomy. Crustacean Issues, 5, 73-87.

Dando, P.R. \& Southward, A.J., 1980. A new species of Chthamalus (Crustacea: Cirripedia) characterized by enzyme electrophoresis and shell morphology: with a revision of other species of Chthamalus from the western shores of the Atlantic Ocean. Fournal of the Marine Biological Association of the United Kingdom, 60, 787-831.

Daniel, A., 1956. The Cirripedia of the Madras coast. Bulletin of the Madras Government Museum, 6(2), 1-40.

Darwin, C., 1854. A monograph on the sub-class Cirripedia...the Balanidae, the Verrucidae, etc. London: The Ray Society.

Dhandapani, K. \& Fernando, S.A., 1994. Fecundity of some sessile barnacles with emphasis on fugitive forms from Porto Novo, South India. In Recent developments in biofouling control (ed. M.F. Thompson et al.), pp. 133-140. New Delhi, Bombay, Calcutta: Oxford IBH Publishing Co. Pvt. Ltd.

Dong, Y., Chen, Y. \& Cai, R., 1980. Preliminary study on the Chinese cirripedian fauna (Crustacea). Acta Oceanologica Sinica, 2, 124-131.

Foster, B.A., 1974. The barnacles of Fiji, with observations on the ecology of barnacles on tropical shores. Pacific Science, 28, 3556.

Foster, B.A., 1990. A new species of Euraphia (Cirripedia, Chthamalidae) from Micronesia. Crustaceana, 58, 309-313.

Hedgecock, D., 1979. Biochemical genetic variation and evidence of speciation in Chthamalus barnacles of the tropical eastern Pacific Ocean. Marine Biology, 54, 207-214.

Hiro, F., 1937. Cirripeds of the Palao Islands. Palao Tropical Biological Station Studies, 1, 37-72.

Hiro, F., 1939. Studies on the cirripedian fauna of Japan. IV. Cirripeds of Formosa (Taiwan), with some geographical and ecological remarks. Memoirs of the College of Science, Kyoto Imperial University, Series B, 15, 245-284.

Hoek, P.P.C., 1883. Cirripedia. Reports of the Scientific Results of the Voyage of H.M.S. Challenger 1873-76, Zoology, VIII (25), $1-169$.

Hoek, P.P.C., 1913. Cirripedia of the Siboga-Expedition. SibogaExpeditie Reports, XXXIb, 129-275.

Karande, A.A. \& Palekar, V.C., 1963. On a shore barnacle Chthamalus malayensis Pilsbry from Bombay, (India). Annals and Magazine of Natural History, Series 13, 6, 231-234.

Kim, H. \& Kim, H.S., 1980. Systematic studies on the cirripeds (Crustacea) from Korea. I. Balanomorph barnacles (Cirripedia, Thoracica, Balanomorpha). Korean Fournal of Zoology, 23, 161-194.

Kim, I.H., 1985. Korean barnacles (Crustacea, Cirripedia, Thoracica). PhD thesis, Department of Zoology, Seoul National University, Korea.
Miller, K.M., Blower, S.M., Hedgecock, D. \& Roughgarden, J., 1989. Comparison of larval and adult stages of Chthamalus dalli and Chthamalus fissus (Cirripedia: Thoracica). Fournal of Crustacean Biology, 9, 242-256.

Newman, W.A. \& Ross, A., 1976. Revision of the balanomorph barnacles: including a catalog of the species. Memoirs of the San Diego Society of Natural History, 9, 1-108.

Nilsson-Cantell, G.A., 1921. Cirripedien-Studien. Zur Kentniss der Biologie, Anatomie und Systematik dieser Gruppe. Zoologische Bidrag frän Uppsala, 7, 75-390.

Nilsson-Cantell, C.A., 1927. Some barnacles in the British Museum (Natural History). Proceedings of the Zoological Society of London, 1927, 743-790.

Nilsson-Cantell, C.A., 1934. Cirripeds from the Malay archipelago in the Zoological Museum of Amsterdam. Zoologische Mededeelingen, Leiden, 17, 31-63.

Nilsson-Cantell, C.A., 1938. Cirripedes from the Indian Ocean in the collection of the Indian Museum, Calcutta. Memoirs of the Indian Museum, 12, 1-81.

Pannacciulli, F.G., Bishop, J.D.D. \& Hawkins, S.J., 1997. Genetic structure of two populations of two species of Chthamalus (Crustacea: Cirripedia) in the north-east Atlantic and Mediterranean. Marine Biology, 128, 73-82.

Pilsbry, H.A., 1916. The sessile barnacles (Cirripedia) contained in the collections of the United States National Museum: including a monograph of the American species. Bulletin of the United States National Museum, 93, 1-366.

Poltarukha, O.P., 1997. Composition, phylogeny and taxonomic position of the subfamily Euraphiinae (Crustacea, Cirripedia, Chthamalidae). Zoologicheskii Zhurnal, 76, 1109-1117. [In Russian.]

Poltarukha, O.P., 2000. Description of a new Chthamalus species with taxonomic observations of the subfamily Chthamalinae (Crustacea, Chthamalidae). Zoologicheskii Zhurnal, 79, 779786. [In Russian.]

Poltarukha, O.P., 2001a. On geographical distribution of Chthamalus moro Pilsbry 1916 (Crustacea, Cirripedia, Chthamalidae). Byulletin' Moskovskogo Obshchestva Ispytatelej Prirodi. Odtel Biologicheskij, 106, 41-43. [In Russian.]

Poltarukha, O.P., 2001b. Materials on variability and taxonomic status of Chthamalus malayensis Pilsbry 1916 and Chthamalus moro Pilsbry 1916 (Crustacea, Cirripedia, Chthamalidae) inhabiting littoral of southern Vietnam. Zoologicheskii Zhurnal, 80, 155-164. [In Russian.]

Pope, E.C., 1965. A review of Australian and some Indomalayan Chthamalidae (Crustacea, Cirripedia). Proceedings of the Linnean Society of New South Wales, 90, 10-77.

Ren, X., 1984. Studies on Chinese Cirripedia (Crustacea). III. Family Chthamalidae. Studia Marina Sinica, 22, 145-163.

Rossel, N.C., 1972. Some barnacles (Cirripedia, Thoracica) of Puerto Galera found in the vicinity of the U.P. Marine Biological Laboratory. Natural and Applied Science Bulletin, Philippines, 24, 143-285.

Southward, A.J., 1976. On the taxonomic status and distribution of Chthamalus stellatus in the north-east Atlantic region. Fournal of the Marine Biological Association of the United Kingdom, 56, 1007-1028,

Southward, A.J., 1983. A new look at variation in Darwin's species of acorn barnacles. Biological Fournal of the Linnean Society of London, 20, 59-72.

Southward, A.J. et al., 1998. Invasion of Hawaiian shores by an Atlantic barnacle. Marine Ecology Progress Series, 165, 119-126.

Stubbings, H.G., 1936. Cirripedia. Scientific Reports of the John Murray Expedition, 1933-1934, 4, 1-70.

Stubbings, H.G., 1961. Some Cirripedia from the Persian Gulf. Annals and Magazine of Natural History Series 13, 4, 171-176.

Tarasov, N.I. \& Zevina, G.B., 1957. Fauna SSSR, new series, 69. Rakoobraznie 6 (1) Usonogi Raki (Cirripedia Thoracica) Morei SSSR. Moscow \& Leningrad: Akademi Nauk. 
Utinomi, H., 1949. Studies on the cirripedian fauna of Japan. VI. Cirripeds from Kyusyu and Ryukyu Islands. Publications of the Seto Marine Biological Laboratory, 1, 19-37.

Utinomi, H., 1954. Invertebrate fauna of the intertidal zone of the Tokara Islands. IX. Cirripedia. Publications of the Seto Marine Biological Laboratory, 4, 17-26.

Utinomi, H., 1962. Studies on the cirripedian fauna of Japan. VIII. Thoracic cirripeds from western Kyusyu. Publications of the Seto Marine Biological Laboratory, 10, 211-239.

Utinomi, H., 1970. Studies on the cirripedian fauna of Japan. IX. Distributional survey of thoracic cirripeds in the southeastern part of the Japan Sea. Publications of the Seto Marine Biological Laboratory, 17, 339-372.
Wares, J.P., 2001. Patterns of speciation inferred from mitochondrial DNA in North American Chthamalus (Cirripedia: Balanomorpha: Chthamaloidea). Molecular Phylogenetics and Evolution, 18, 104-116.

Wu, R.S.S., 1975. The distribution of littoral barnacles in Hong Kong. In Pacific Science Association, Special Symposium on Marine Sciences (ed. B. Morton), pp. 146-153. Hong Kong: Government Printer.

Zullo, V.A., 1968. Catalog of the Cirripedia named by Henry A. Pilsbry. Proceedings of the Academy of Natural Sciences of Philadelphia, 120, 209-235.

Submitted 7 January 2003. Accepted 10 June 2003. 